\title{
Work-in-Progress-Immersing E-facilitators in Training: The Perspective of Project FAVILLE - Facilitators of Virtual Learning
}

\author{
Susanne Lattke \\ German Institute for Adult \\ Education - Leibniz Centre for \\ Lifelong Learning \\ Germany \\ lattke@die-bonn.de
}

\author{
Leonel Morgado \\ Universidade Aberta \& \\ INESC TEC \\ Portugal \\ leonel.morgado@uab.pt
}

Lina Morgado

LE@D, Universidade Aberta Portugal

lina.morgado@uab.pt

\author{
Ana Paula Afonso \\ LE@D, Universidade Aberta \\ Portugal \\ aafonso@lead.uab.pt
}

\author{
Filipe Penicheiro \\ LE@D, Universidade Aberta \& \\ INESC TEC \\ Portugal \\ filipe.penicheiro@uab.pt
}

\author{
José António Moreira \\ LE@D, Universidade Aberta \\ Portugal \\ jmoreira@uab.pt
}

\begin{abstract}
The paper presents the e-facilitator concept and explores the perspective of some professionals in the field (stakeholders) on this role and its competencies. Facilitation in virtual learning environments is a growing challenge when more and more learners find their way to online learning platforms and many universities adapt their courses to digital environments since the global pandemic forced many people to stay at home.
\end{abstract}

Index Terms-e-learning, virtual learning facilitators, efacilitators, immersing e-facilitators

\section{INTRODUCTION}

Success in the learning process of e-learning goes beyond the mechanics of students interacting with contents or with their peers and tutors/lecturers. It depends on sustaining that interaction, its dynamics, over the full length of an e-learning course [1].

A role which has been acknowledged towards encouraging, supporting, and maintaining these dynamics is that of efacilitator [2]. However, it's contours are fuzzy and this creates uncertainty regarding the role itself, its responsibilities, and the competencies that an e-facilitator should master to play this role successfully [1], [3].

In the FAVILLE "Facilitators of virtual learning" project, we are developing a training program for e-facilitators. To address the fuzziness of the concept, we developed a multinational effort to interview a panel of e-learning stakeholders, as well as a survey of documentation, as a first attempt to clarify the role and competencies of e-facilitators.

\section{BACKGROUND}

\section{A. FAVILLE}

FAVILLE, "Facilitators of Virtual Learning" is a project funded by the European Commission that joins seven different partners from five countries, from private and public sectors: one national institute for adult learning, (German Institute for Adult Education Leibniz Centre for Lifelong Learning Germany), two Open Universities, (Hellenic Open University/Greece and UAbUniversidade Aberta/Portugal), two non-profit private organisations (ASTRA and ENTRE, Slovakia) and two private companies (HT S.r.L., Italy and IDEC, Greece).

Aware of that, the project aims to enhance the quality standards for facilitation in virtual learning environments and to provide the skills and competences that facilitators of virtual learning need to develop their techniques.

The aim of the project will be achieved by creating a specific training programme for virtual learning facilitators, complemented by a web application and the development and validation of a skill-framework. Keeping in mind the international nature of these virtual learning platforms, intercultural teams were included in the training programme development which will be available in five different languages: Italian, German, Greek, Portuguese and Slovak, potentially reaching over 380 million speakers.

\section{B. Virtual Learning Facilitators}

Current programmes for e-learning teachers and trainers focus more on the use of the learning platforms and not on facilitation techniques and many times the "technology only" focus prevails over educational technology and pedagogics.

Authors like Salmon [4], Denis et al [5] or Martin et al [6] present diverse roles and functions for virtual facilitators.

FAVILLE envisions the virtual learning facilitator as someone who "acts in the virtual class as a motivator, supporter - someone who facilitates the learning environment, team dynamics, communication and collaboration among the participants and with the trainer". 
Acquiring these skills presupposes "the immersion of the facilitator" [6], in this environment and, therefore, training in an online context.

It has not been clarified how this immersion of the facilitator can be achieved, so we will consider for this work the perspective on immersion put forth by Beck et al. [7] and will leverage it to interpret our results.

\section{METHODOLOGY AND CURRENT WORK}

In order to sustain some of the arguments presented, FAVILLE partner's developed a needs analysis including a desk research and expert interviews in five European countries to map the state of the art regarding e-facilitators status and to establish their competencies and qualification needs.

The desk research aimed at providing an overview on existing information regarding virtual learning facilitators and their training needs in the partner countries. Together with the results of the expert interviews, the desk research provided the knowledge base for the conceptual development of the FAVILLE training course.

Experts interviewed included a variety of profiles including staff from universities (including distance universities); professors, researchers, tutors; company trainers; teachers of adults from various fields; media/ICT experts; training managers; project managers from NGOs and consultants among others.

A total of 36 interviews were conducted by the seven project partners (5 interviews in Germany, Italy and Portugal, respectively, 10 interviews in Greece and 11 interviews in Slovakia).

Both the desk research and the expert interviews were conducted by all project partners using shared instruments (desk research template, interview guideline with key questions) so as to yield comparable information across the partnership. The research thus provided information on five different areas: Perception of "facilitation" on different countries; relevance of e-learning facilitation as a professional task and professional role; regulatory context of e-learning facilitation: access requirements, professional standards; characteristics of elearning facilitators; validation opportunities for e-learning facilitators.

In order to determine the competence profile for virtual learning facilitators, the corresponding text sections of the desk research reports and the expert interviews summaries were analysed using an inductive category formation approach from the qualitative content analysis.

\section{RESULTS AND DISCUSSION}

FAVILLE desk research and interviews found and confirmed some interesting inputs, namely that virtual learning facilitators need a broad range of competencies. Technical skills; socio-communicative competence skills, specifically for ICTbased communication; professional awareness and adult learning principles. Methodical skills (knowledge and application skills of facilitation methods and tools in the online environment) and managing/planning/organizational/ skills are also recognized as of key importance in the need's analysis conducted.

Technology and technological skills alone are not sufficient to enable high quality online learning. For the learning success it is critical that the facilitator is able to plan and implement a pedagogically meaningful setting, using the specific possibilities (and coping with the limitations) of the online environment. (Psycho) pedagogical and planning skills are therefore of paramount importance.

Although there are many aspects that are common both to face-to-face learning and to conventional distance learning, one cannot assume that pedagogical competences and approaches of these modalities are automatically transferable to the online environment. Acquiring these skills presupposes "the immersion of the facilitator" [6] in this environment and, therefore, training in an online context. We can also consider these areas as highly relevant for supporting immersive learning. E-Facilitators in immersive learning environments will gain by developing their technical skills but also their socio-communicative competencies and managing/planning/organizational/skills [7].

\section{CONCLUSIONS}

Current programmes for e-learning teachers and trainers focus more on the use of the learning platforms and not on facilitation techniques and many times the "technology only" focus prevails over educational technology and pedagogics.

FAVILLE envisions the e-facilitator as someone who "acts in the virtual class as a motivator, supporter - someone who facilitates the learning environment, team dynamics, communication and collaboration among the participants and with the trainer".

The needs analysis conducted by the FAVILLE project revealed more information about the views of different stakeholders on the role of virtual learning facilitators, the uncertainty regarding the role itself, its responsibilities, and the competencies that an e-facilitator should master to play this role successfully.

The crux of the results points towards the necessity of immersing the facilitator to support its development of core efacilitation skills. This immersion, following the theoretical perspective of Beck et al. [7] implies that immersive e-facilitator training should consider narratives, challenges, and systems that immerse them in the daily exercise and awareness of sociocommunicative competencies and their management, planning, and organizational skills, as well as the technical skills required for e-facilitating in virtual learning environments.

\section{ACKNOWLEDGMENT}

The present work was developed under the FAVILLE project, co-funded by the Erasmus+ programme of the European Union, FAVILLE: 2019-1-SK01-KA204-060 711 


\section{REFERENCES}

[1] C. Karachristos, T. Kouvara, T. Orphanoudakis, E. Stavropoulos, Z. Batsi, (2020). Defining e-learning facilitation - The Greek case study. In Proceedings of ICERI2020 Conference

[2] P. Goodyear, G. Salmon, J. Spector, C. Steeples, \& S. Tickner, (2001). Competences for online teaching: A special report. Educational Technology Research and Development, 49(1), 65-72. .

[3] D.R. Garrison, \& T. Anderson, (2003). E-Learning in the 21st Century.Routledge

[4] G. Salmon, (2000). E-moderating: The key to teaching and learning online. London: Kogan Page.

[5] B. Denis, P. Watland, S. Pirotte \& N. Verday (2004). Roles and Competences of e-Tutor, In Banks, S., Goodyear, P., Hogdson, V \& Jones, C. (Editors). Proceedings of IV Networked Learning Conference, 5th-7th April, p.150-157, Lancaster University

[6] F. Martin, K. Budhrani, S. Kumar, \& A. Ritzhaupt, (2019). Awardwinning faculty online teaching practices: Roles and competencies. Online Learning, 23(1), 184- 205.

[7] D. Beck, L. Morgado, \& P. O'Shea, (2020). Finding the gaps about uses of immersive learning environments: a survey of surveys. Journal of Universal Computer Science, 26, 1043-1073 